\title{
Rasestumise, lapseootuse ja sünnitusega seotud kogemuslugude funktsioonidest www.perekool.ee foorumite suhtluses
}

\author{
Folkloristlik teemaanalüüs ${ }^{1}$
}

\author{
Maili Pilt \\ Tartu Ülikooli folkloristika doktorant \\ maili.pilt@ut.ee
}

\begin{abstract}
Teesid: Artiklis vaatlen Eesti Ämmaemandate Ühingu internetiportaali www.perekool.ee foorumeisse Rasestumine, Lapse ootamine ja Sünnitus kirjutatud kogemuslugude funktsioone. Vaatluse all on nelja rühma kogemuslood: 1) rasestuda soovivate naiste (triibupüüdjate) lood, 2) kehavälise viljastamise kogemusega naiste (ivf-kate) lood, 3) lapseootajate (kõhukasvatajate) lood ja 4) sünnitanud naiste e sünnituslood. Teemapüstituse ajendiks on küsimus, millist rolli või eesmärki täidavad naiste isiklikke kehalisi kogemusi vahendavad lood internetirühmas - täpsemalt, mil viisil toimib üks rasestumisele, kehavälisele viljastamisele, lapseootusele või sünnituskogemusele keskenduv lugu kui abipalve ja lohutus, infovahetus ja nõuanded, hoiatus, eneseesitlus ning ajaviide. Lisaks on kogemuslugude funktsioonide vaatluse sihiks heita pilk laiematele tähendustele ja ajenditele, miks jagavad naised oma isiklikul elul põhinevaid delikaatse sisuga lugusid kergesti ligipääsetavas internetifoorumis. Käsitlus põhineb perioodil 2012-2018 Perekooli foorumisse kirjutatud kogemuslugude ning nendega seotud kommentaaride kvalitatiivsel sisuanalüüsil ja diskursuseanalüüsil.
\end{abstract}

Märksõnad: internet, kehaväline viljastamine, kogemuslood, lapseootus, rasestumine, sünnitus

\section{Sissejuhatus}

Lapse sünd on ime - vähemasti on nii ikka öeldud. Samas võib selle ime ootus tekitada naises segaseid tundeid, venida mõnikord väga pikaks, olla problemaatiline või jääda sootuks tulemuseta. Last saada sooviv ja last ootav naine võib tunda end isoleerituna või üksikuna. Teda võivad vallata nõutust tekitavad mõtted ja tunded - kas see, mis tema kehaga toimub, on ikka normaalne, kas rasestumine ja sünnitus õnnestuvad või kuidas tuleks tal eri situatsioonides toimida. Ette võib tulla ka traagilisi hetki. Naistel, kelle rasedus katkeb, peetub 
või kes elavad üle nurisünnituse, tuleb toime tulla lapse kaotusest tingitud leinaga: miks nii juhtus, kuidas eluga edasi minna, ning mil viisil leida oma murele leevendust? Nii on igal last saada üritanud ja sünnitanud naisel oma lugu, mida ta endaga kaasas kannab, ning mida võib ta soovida teistega jagada.

Siiski ei ole rasestumisest, lapseootusest ning sünnitusest rääkimine ja vajaliku info ja abi leidmine alati lihtne. Naise lähikonnas ei pruugi olla sobivat, vastava kogemuse ja teadmistega isikut, kellega huvipakkuval või murettekitaval teemal vestelda. Ka ei pruugi naine tahta jagada enda kogetut, mõtteid ja tundeid pereliikmete, tuttavate või ka meditsiinipersonaliga. Konkreetne teema võib tunduda liialt delikaatne, et seda silmast silma kohtumistel jutuks võtta või tunneb naine mingil põhjusel, et teda ei mõistetaks. Sellisel juhul pakub tänapäeval olulist alternatiivi internetisuhtlus - naised saavad rasestumise, lapseootuse ja sünnitusega seotud teemadel arutada, vajalikku infot otsida ja kogemusi jagada eriilmelistes internetikeskkondades nagu sotsiaalvõrgustikud, veebilehed, veebipäevikud ning vestlusfoorumid. Üks sedalaadi keskkondi on ka eestikeelne veebiportaal www.perekool.ee. Perekool on 2000. aastal Eesti Ämmaemandate Ühingu poolt loodud veebileht, mis koondab inimesi, kes on huvitatud pere loomise ja suhte teemadest. Keskkond sisaldab nii teemakohaseid artikleid kui ka (2018 sügise seisuga) üheksatteist temaatilise alafoorumiga vestlusringi (Perekooli keskkonnast vt lisaks Pilt 2013a: 27-40; Reinaus 2008: 34).

Uurijad on Perekooli-laadsetes internetikeskkondades osalemist soodustava tegurina nimetanud tõsiasja, et sealsed vestlusringid võimaldavad jagada oma isiklikke ja intiimseid kogemusi, mõtteid ja tundeid ilma vajaduseta siduda neid oma isikuga - naine võib jääda anonüümseks või kasutada pseudonüümi (vt nt Kaliarnta \& Nihlén-Fahlquist \& Roeser 2011: 281-282, 284-285; Wright \& Bell 2003: 40, 43). Niisamuti on sedalaadi interneti vestlusringidesse suundumise oluliseks ajendiks peetud kogukonnaloomet - naiste soovi koondada enda ümber saatusekaaslasi, kel on sarnased huvid ja kogemused, ning kel on seetõttu eeldus üksteist mõista (Cohen \& Raymond 2011: 941-942; Kõiva 2009: 171-172, 180; Malik \& Coulson 2008: 106-108; Terp Høybye \& Johansen \& Tjørhøj-Thomsen 2005: 216-217; Reinaus: 2007: 17-18; Sharf 1997: 68-69).

Analoogselt teiste rasestumise, lapse ootuse ning sünnitusega seotud teemadele keskenduvate internetirühmadega on Perekooli foorumites kohtuvate naiste vestlustest kujunenud välja konkreetsele veebikogukonnale iseloomulikud suhtlusviisid ja tavad. Nii täidavad Perekooli foorumite suhtluses keskset rolli nii küsimus-vastus stiilis arutelud, kuid ka kogemuslood (vrd Reinaus 2007: 18-19). Viimased on muust infovoost kergesti leitavad ning oma vormi poolest selgelt eristuvad pikemad narratiivid, milles naised jagavad rasestumise, lapse ootuse ja sünnitusega seotud kogemusi, mõtteid ja tundeid. Ühtlasi kirjeldavad 
need lood detailselt naiste kehalisi kogemusi ning meditsiiniprotseduure, mis naistel tuleb läbida.

Käesolevas artiklis keskendun Perekooli alafoorumeisse Rasestumine, Lapse ootamine ja Sünnitus kirjutatud kogemuslugude funktsioonidele. Teemapüstitus on ajendatud küsimusest, milline eesmärk või roll on lugudel internetirühma toimimise seisukohast nende kirjapanijate jaoks, ning nende jaoks, kes neid lugusid foorumis loevad ja kommenteerivad. Samuti on kogemuslugude funktsioonide vaatluse sihiks heita pilk laiematele tähendustele ja ajenditele, miks jagavad naised oma isiklikul elul põhinevaid ja delikaatse sisuga lugusid kergesti ligipääsetavas internetifoorumis.

\section{Teoreetilisi lähtekohti}

Internetifoorumisse kirjutatud lood, mis keskenduvad rasestumise, lapse ootuse ja sünnitusega seotud kogemustele, ning mida nimetan käesolevas käsitluses nende sisu ja rõhuasetuse tõttu kogemuslugudeks, sarnanevad neile, mida Sandra Stahl (1986: 268-269) kirjeldab kui isikukogemuse jutte (ingl personal experience story). Stahli järgi on need harilikult esimeses isikus esitatud lood, mille koostab jutustaja ja mis põhinevad tema elus tegelikult aset leidnud juhtumitel. Seejuures võib loos taasloodud kogemuseks olla nt lõbus jutustus lapsepõlvest, sündmus koolis või tööl, kokkupuude üleloomuliku või seletamatuga, valulik õppetund vm. Linda Dégh (1985) on märkinud, et kogemusjuttude loomiseks võib pakkuda materjali iga osa eluloost hällist hauani, kaasa arvatud tähtsad pöördepunktid ja pereelu, töö, meelelahutuse, pidustuste, usu, haiguste või reisimisega seotud pisiasjad. Analoogselt käesoleva uurimuse keskmes olevatele kogemuslugudele on ka Lena Marander-Eklund (2001: 177; 2002: 113) viidanud naiste lugudele sünnitusest kui isikukogemuse juttudele, nentides, et need on väljendused naiste lapsesaamise kogemusest.

Isiklikke kogemusi vahendavaid lugusid on liigitatud selle põhjal, mis laadi kogemustele need keskenduvad. Ühelt poolt on uurijad nimetanud jutte, mis kõnelevad ühekordsetest sündmustest (nt lood reisidest, võistlustest, pidudest) ja nendega seotud elamustest ega kätke üldiselt inimese elu muutvaid seiku. Teiselt poolt aga on isikukogemuse juttudest räägitud seoses lugudega, mis on seotud inimese elu olulisemate sündmustega, elu pöördepunktidega või mõne pikaajalise perioodiga jutustaja elust (nt kooliminek, abiellumine, elu kroonilise haigusega vm), ning mis vahendavad seega nn erilisi kogemusi või elukogemust ja moodustavad ühtlasi ka olulise osa jutustaja minapildist (vt nt Salmi-Niklander 2009: 20-24; Squire 2013: 48-49; Lundby 2013: 44). Interne- 
tifoorumisse naiste poolt kirjutatud rasestumise, lapseootuse ja sünnitamise kogemusi vahendavad lood kuuluvad viimati nimetatute hulka.

Käesolev käsitlus on osa laiemast folkloristika-alasest uurimusest, mille keskmes on eestikeelseisse pere- ja suhtefoorumeisse kirjutatud delikaatse sisuga kogemuslood kui üks internetirühma kollektiivsuse ilminguid. Täpsemalt lähtub siinne teemapüstitus folklooriuurimise funktsionalistlikust vaatest, mille järgi on igal nähtusel, olgu see siis jutt, uskumus, tegevus või ese, oma funktsioon. Kusjuures termin funktsioon tähistab rolli või eesmärki, mida folkloorne nähtus täidab või on mõeldud täitma konkreetsetel asjaoludel. Tekstide funktsioonide vaatluse sihiks on jõuda nende otstarbe või tähendusteni rühma liikmete (käesoleva artikli kontekstis nii kogemuslugude kirjutajate kui ka lugejate) silmis, kelle suhtluses need ilmnevad ja kellele need on olulised (vt ka Glazer 1997: 386; Honko 1984; Kamppinen 2014: 8-10; Squire \& Andrews \& Tamboukou 2013: 5-7; Squire 2013: 50; Phoenix 2013: 72-73).

Rasestuda soovivate, last ootavate või juba sünnitanud naiste internetikeskkondadesse postitatud kogemuslugude funktsioonid on interdistsiplinaarne uurimisvaldkond ning osa laiemast diskursusest, mille raames keskendutakse osalemisele pere-, suhte- ja terviseteemalistes internetirühmades. Internetifoorumeisse kirjutatud kogemuslugude funktsioone uurides olen Eesti folkloristide varasematest käsitlustest leidnud tuge Mare Kõiva patsientide narratiividele keskenduvatest uurimustest (vt Kõiva 2009; 2010). Oma käsitluses keskendub Kõiva diabeedihaigete internetirühmadele ning küsimusele, kuidas isiklike lugude jagamine, suhtlemine ja väitlemine aitab inimestel oma haigusega hakkama saada. Muuhulgas vaatleb Kõiva probleemi, kuivõrd võib internetikogukond ja sealne suhtlus toimida kui varasema ühiskondliku ja peresuhtluse täiendus ja asendus (2010: 245). Niisamuti olen võrdlusmaterjali leidnud Reeli Reinause magistriväitekirjast "Enesepresentatsioon virtuaalses kogukonnas sünnituslugude ja Perekooli foorumi kommentaaride näitel” (vt Reinaus 2007). Reinause fookus on sünnituslugudel kui eneseesitlusvahendil. Oma töös otsib ta vastuseid küsimustele, kuidas presenteerivad naised sünnituslugudes enda keha, sellega toimunut ja sünnitamisega seotud hoiakuid, ning mil viisil loovad nad seeläbi enese identiteeti teiste grupiliikmete jaoks ning kujundavad rühmaidentiteeti. Oluliseks allikaks on olnud ka mitmed meditsiiniantropoloogia, naisuurimise ja psühholoogia valdkonna tööd (vt nt Cohen \& Raymond 2011; Kaliarnta \& Nihlén-Fahlquist \& Roeser 2011; Malik \& Coulson 2008; Sharf 1997; Terp Høybye \& Johansen \& Tjørhøj-Thomsen 2005; Toscano \& Montgomery 2009; Wright \& Bell 2003). Viimastes on keskne nn tugirühma temaatika, kus internetirühmade suhtluses nähakse olulist psühholoogilist tuge ning alternatiivi silmast silma kohtuvatele tugirühmadele. Internetisuhtluse ja kogemuslugude vaatluse kaudu otsitakse vastust küsimusele, millist rolli mängib 
internetirühmades osalemine oma kogemusega hakkamasaamisel. Niisamuti püütakse jõuda naiste tegelike kogemusteni, et neid paremini mõista, misläbi on võimalik pakkuda neile näiteks vajalikke tugiteenuseid, nagu psühholoogiline nõustamine rasedatele või kehavälise viljastamise protseduuri läbivatele naistele. Abiks on olnud ka Shani Orgadi sotsioloogiline käsitlus "Storytelling Online. Talking Breast Cancer on the internet" (2005), kus autor lahkab internetis jutustamise eripärasid rinnavähiga naiste internetifoorumite suhtluse näitel. Selles käsitluses kritiseerib Orgad muuhulgas varasemaid käsitlusi, mis vaatlevad naispatsientide internetirühmades osalemise ning seal oma elul põhinevate lugude jutustamise funktsioone. Orgad nendib, et suur osa sellistest käsitlustest loovad pelgalt abstraktseid kategooriaid internetirühmades osalejate tegevuste funktsioonidest nagu "infovahetus", "emotsionaalne tugi" vm, kuid jätavad kõrvale laiema sotsiaalkultuurilise konteksti - need ei ava, mis peitub ühe või teise funktsioonide-kategooria taga - ei selgu, mida ja miks inimesed tegelikult internetis teevad, ning milline sügavam tähendus on neil tegevustel osalejate silmis (samas: 16-17). Orgadi enda uurimuse fookus on internetis jutustamise protsessil ja viisidel, kuidas internetikeskkond seda mõjutab, samuti sellel, kuidas seostub rinnavähipatsientide internetikogemus nende internetivälise kogemusega.

Käesoleva, kogemuslugude funktsioonidele keskenduva käsitluse rõhuasetus on jutustamisel kui tähendusi looval protsessil. Kogemuslugude funktsioonide kategooriate loomine ei ole eesmärk omaette, sihiks on vaadelda, kuidas üks või teine kogemusloo funktsioon internetirühma suhtluses avaldub. Seejuures on kavas heita pilk nii online kui ka offline kontekstidele, neile põhjustele, suhetele ja arusaamadele, mis naisi foorumis oma lugusid jagama ja teiste lugusid lugema ajendab.

\section{Aines ja meetod}

Perekooli foorumi kasutajad ei ole ühtne rühm, alafoorumite infovoos eristuvad sarnaste kogemuste ja huvidega naiste siserühmad. Seetõttu olen ka vaadeldavaid kogemuslugusid rühmitanud selle järgi, kuidas nende kirjapanijad endid nimetavad, ning millistele kogemustele neis lugudes keskendutakse. Täpsemalt vaatlen nelja rühma kogemuslugusid.

Esimeseks vaatlusaluseks rühmaks on "triibupüüdjate" lood Rasestumise alafoorumis. Triibupüüdjateks nimetavad Perekooli foorumeis end naised, kes loodavad rasestuda ning tahavad näha kahte triipu oma rasedustestil. Kuigi triibupüüdjate hulka arvatakse rühmasuhtluses nii need, kes soovivad esmakordselt rasestuda kui ka need, kes on seda juba pikka aega üritanud, jagavad 
oma lugusid enamasti just pikaajalised triibupüüdjad - need, kel on olnud rasestumise, kuid ka juba saavutatud raseduste katkemiste ning peetumistega probleeme nii pika perioodi jooksul, et neil on oma lugu, mida rääkida. Sealhulgas saab pikaajaliste triibupüüdjate lugusid liigitada veel selle järgi, mis on neis kirjeldatud rasestumisega, raseduse katkemise või peetumisega seotud probleemi fookuseks - on need siis polütsüstilised munasarjad, endometrioos (krooniline haigus, mille puhul emakaõõnt vooderdava limaskesta taoline kude paikneb kolletena väljaspool emakat), nn seletamatu viljatus (kui arstid ei ole veel põhjust välja selgitanud), meespoole viljatusprobleemid, loote geenirike vm. Triibupüüdjate lugude keskmes on sageli lapsesooviga naiste läbielamised, kogemused ja emotsioonid, mis seostuvad lastetusega, lapse kaotusega ning meditsiiniprotseduuridega. Kuigi triibupüüdjate lugusid võib leida ka muu suhtluse hulgast, on suur osa neist koondunud ajaliselt määratletud teemaalgatuste alla nagu nt "aprilli triibupüüdjad 2017".

Teine rühm lugusid on "ivf-kate" lood Rasestumise alafoorumis. Nimetus "ivfkad" tuleneb inglise keelsest lühendist IVF (in vitro fertilization) ning tähendab kehavälist viljastamist. Seega on ivf-kate lood kirjutatud naiste poolt, kelle viimane võimalus last saada on kehaväline viljastamine. Sarnaselt triibupüüdjate lugudele, keskenduvad need lood probleemidele rasestumisel, sedapuhku aga fookusega kehavälise viljastamise protseduuril. Naised jagavad rühmakaaslastega oma lugu, kuidas nad kehavälise viljastamise otsuseni jõudsid, millist ravi nad saavad, ning millised on olnud nende edusammud - kui palju munarakke (ivf-kate kõnepruugis "mammud") õnnestus viljastada ja külma panna, kui palju siirdati, ning kas ja millal rasestumine ja lapsesaamine õnnestus. Nagu triibupüüdjategi puhul võib ivf-kate lugusid leida nii foorumisse regulaarselt loodavate teemade all nagu "ivf-kate aprill 2017" kui ka muu suhtluse osana.

Kolmandaks vaadeldavaks grupiks on "kõhukasvatajate" lood Lapse ootamise alafoorumis. Need on lood, mis vahendavad naiste kogemusi, mõtteid ja tundeid seoses lapseootusega. Fookus võib nende lugude puhul olla raseduse ajal naise kehas toimuvatel muutustel ja sellega seotud emotsioonidel, lapse sünniga seotud ettevalmistustel, meditsiinilistel protseduuridel, mida last ootaval naisel läbi tuleb teha, suhtlusel ämmaemandate ja arstidega, murel veel sündimata lapse tervise pärast, hirmul sünnituse ees, kuid ka lapsekaotusel raseduse hilises järgus või sünnitusel. Kõhukasvatajad jagavad enda lugusid nii spetsiaalsete teemade all nagu lapse oodatavale sünnikuule viitavad "maikad 2016" või “aprillikad 2017" või siis muu suhtluse osana.

Neljanda grupi moodustavad sünnituslood, mida võib leida nii Lapse ootamise kui ka Sünnituse alafoorumeist. Need on lood, mis keskenduvad sünnitamise kogemusele, kuid võivad sisaldada ka selle eellugu, rasestumise ning lapseootusega seonduvat. Olenevalt sellest, kas naise teekond lapse sünnini on 
olnud probleemivaba või mitte ning sellest, kuidas on kulgenud sünnitus, leidub nende lugude hulgas nii positiivse kui ka negatiivse alatooniga tekste, samuti nii probleemikeskseid kui ka lihtsalt oma kogemusi vahendavaid jutustusi. Kui võrrelda seda, kui palju ja mislaadi sünnituslugusid kirjutati Perekooli foorumis mõned aastad tagasi (vrd Reinaus 2007: 90), on tendents, et sünnituslugusid (iseäranis probleemideta raseduse ja sünnituse korral) jagatakse aina vähem. Niisamuti ei kirjutata sünnituslugusid kuigi tihti enam Sünnituse alafoorumisse, vaid eelistatakse seda teha siserühmas (näiteks maikuu beebiootajate või ivf-kate grupis), kellega lapseootuse ajal suheldi ning kellega oma rõõme ja muresid jagati.

Kõigile nimetatud kogemuslugudele on iseloomulik, et nende kirjapanijad nimetavad neid lugusid foorumiteemade pealkirjades või lugudes endis kui "minu lugu" või "meie lugu". Seetõttu on viimased olnud ka märksõnadeks, mille abil olen kogemuslood foorumikeskkonnast üles leidnud. Ühtekokku olen perioodil 2012-2018 kogunud foorumikasutajate igapäevasuhtluse vaatluse ning foorumikeskkonna otsingumootori abil 755 teksti. Viimaste hulgas on 56 triibupüüdja lugu, 43 sünnituslugu, 15 ivf-ka lugu, 39 kõhukasvataja lugu ning 602 lugudega seotud kommentaari. Seejuures on minu fookus olnud sellel, mida saab foorumisse kirjutatud kogemuslugude funktsioonide kohta öelda lugude sisu, nendega seotud foorumikommentaaride ning neist moodustuvate narratiiviahelate põhjal. Viimaste puhul pean silmas kõiki ühe foorumiteema raames kirja pandud tekste: esialgset kogemuslugu, selle täiendusi, kommentaare ning teiste foorumiliikmete lugusid, mis on kirjutatud reageeringuna teemaalgataja loole (vrd Kõiva 2010: 222). Tekstide analüüsimisel olen kombineerinud kvalitatiivset sisuanalüüsi ning diskursuseanalüüsi (vt Laherand 2008: 290-291, 309-325). Sisuanalüüsi abil märkisin ära kogemuslugudes ja kommentaarides esilekerkivaid sõnu ja lauseosi, mis viitasid kirjutajate ajendeile. Nii lõin kategooriad, mille alusel olen pealkirjastanud käesoleva artikli kogemuslugude funktsioone käsitlevad alapeatükkide pealkirjad. Nendeks on: lohutus ja abi, infovahetus ja nõuanded, hoiatus, eneseesitlus ja ajaviide. Diskursuseanalüüsi käigus pöörasin tähelepanu kogemuslugude kirjutajate ja lugejate dialoogile - kaardistasin kogemuslugudes sisalduvaid pöördumisi lugejate poole ning tagasisidet, mida on teised foorumi liikmed neile lugudele andnud. Selle sihiks oli välja selgitada, milles täpselt üks või teine kogemusloo funktsioon internetirühma suhtluses väljendub - teisisõnu, mis rolli täidavad kogemuslood internetirühma toimimise seisukohast ning millised on need laiemad tähendused ja põhjused, miks naised foorumis oma kogemuslugusid jagavad.

Võttes arvesse vaadeldavate kogemusjuttude isiklikku ja delikaatset sisu ning lugude kirjutajate võimalikku privaatsusevajadust ei ole käesolevas käsitluses kasutatud näidetena terviktekste, vaid enamasti üksnes sedalaadi 
katkeid kogemuslugudest ja nende kirjutajate ning lugejate dialoogist, mis illustreerivad kogemuslugude funktsioone internetirühmas. Samadel põhjustel olen eemaldanud tekstidest isikutele ja asukohtadele viitava info ning asendanud kasutajanimed ja lugude pealkirjad koodidega (uurija eetilistest valikutest delikaatse sisuga kogemusjuttude uurimisel vt lisaks Pilt 2013b: 164-171; Pilt 2017: 165-166).

\section{Lohutus ja abi}

Perekooli Rasestumise, Lapse ootamise ja Sünnituse alafoorumite postitustest nähtub, et kogemuslood võivad pakkuda lohutust ja abi nii nende kirjutajaile kui ka lugejaile. Lugudest ilmneb, et nende kirjapanijad võivad leida tuge juba üksnes kirjutamise tegevusest. Näiteks on pikaajalised triibupüüdjad ja ivf-kad põhjendanud oma loo kirjapanekut asjaoluga, et neil on vaja "endast mure välja kirjutada", sest antud toiming pakub nende probleemile leevendust ning aitab sellega paremini toime tulla. See tähelepanek seostub varasemate autorite mõttega, et oma loo jagamisel internetikeskkonnas on naistele omamoodi teraapiline mõju. Kogemuse sõnadesse panemine ja selle kirjeldamine kirjalikus vormis võimaldab kogetut analüüsida, sellest paremini aru saada ning leida nii viis, kuidas selle kogemusega edasi elada (vt nt Asplund Ingemark 2013: 8; Kõiva 2009: 171; Marander-Eklund 2000: 417, 2001: 184-188; Polkinghorne 2013: 34-40).

Oluline roll on rühmaliikmete psühholoogilisel toel, mida oma loo jagamine pakub. Kogemuslugudest tuleb esile, et sageli jagatakse neid foorumis seetõttu, et ei leita vajalikku abi ja tuge oma lähikondlastelt või ka meditsiinipersonalilt, kelle arvamus naise seisundist ei lange kokku sellega, mis viimane tegelikult mõtleb ja tunneb. Erineda võivad arusaamad, mida peetakse rasestumise, lapse ootuse ja sünnituse puhul “õigeks" või "valeks", "normaalseks" või "ebanormaalseks". Niisamuti ei pruugi lähikondlastel ning meditsiinipersonalil olla piisavalt aega naise probleemi süveneda. Tihtilugu ei haaku ka naise ja teda füüsilises ruumis ümbritsevate inimeste kogemused, mistõttu on viimastel keeruline naise murest aru saada ning vajalikku abi pakkuda. Näiteks kajastatakse oma lugudes, kuidas arst ei ole soostunud tugevates valudes vaevlevale naisele andma tugevamaid valuvaigisteid, nentides, et need valud on naistel "normaalsed". Niisamuti kirjutavad naised oma lugudes, kuidas need, kel endal lapsesaamisega probleeme ei ole olnud, ei mõista pikaajalise lapseootusega seonduvat muret, või kuidas IVF-protseduuri peetakse vabaks valikuks ("milleks on vaja kunstlikult lapsi treida") ning lihtsaks viisiks lapse saamisel, teadvustamata, et see on naisele nii füüsiliselt kui ka psüühiliselt väga koormav, ning et tege- 
likkuses õnnestub vaid väike protsent kõigist IVF-katsetest (vrd ka Kaliarnta \& Nihlén-Fahlquist \& Roeser 2011: 281, 283-284).

Aspekti, et oma loo jagamisega foorumis loodetakse lohutust ja abi, mida ei leita füüsilises ruumis, ning et tõeliselt mõista ja aidata saab rasestumise ja lapseootusega seotud probleemidega naist vaid see, kes on ise midagi sarnast kogenud, illustreerivad järgnevad kaks tekstikatket pikaajaliste triibupüüdjate lugudest. Esimeses tõdeb autor, et ta ei saa oma lähikondsetega muret jagada, sest viimastel pole rasestumisega probleeme olnud ja seepärast ei ole põhjust neilt ka mõistvat suhtumist loota. Teises näites vihjab autor, et internetirühmakaaslased on ainsad, kes ei mõista hukka ega hakka ütlema, et ei tasu põdeda, kui rasestumine ei õnnestu.

\section{Triibupüüdja lugu nr 56}

Hakkasid päevad. Mõtlesin et mis siis ikka, pettumus on natukene aga saan hakkama, aga ei. Löök oli vist tugevam, kui ootasin, sest hakkasin nutma. Nutsin oma valu ja pea 2 aastat üritamist välja, vähemalt tundub nii. Hetkel tundub lootusetu seis olevat, kellegagi oma muret jagada ei saa ja kui saaks, keegi ei mõista, sest neil on rasedused kiirelt tulnud ja paluvad positiivsed olla. Raske on. Siirad tänusoovid ka teile, ilma teieta sel teel oleks veel raskem.

\section{Triibupüüdja lugu nr 16}

[---] Ma ei ole sõbrannadega ega teiste tuttavatega jaganud oma ammust suurt soovi saada kolmas laps. Teiega siin tundub ainuke koht kus ei mõisteta hukka ja ei hakata ütlema, et ära põe, küll kõik laabub... [---]

Seda, kuidas foorumiliikmed üksteist vastastikku lohutavad ja abistavad, näitab järgnev dialoog lapse kaotanud naiste kogemuslugudest. Esimeses loos jagab autor oma kogemust täiesti terve lapse kaotusest raseduse 17. nädalal ja palub abi, kuidas leinaga toime tulla. Teine tekstikatke pärineb loost, mis on kirjutatud tagasisidena esimesele loole. Kirjutab naine, kes on pidanud sarnase kogemuse üle elama, ning annab nõu, kuidas kurva sündmusega toime tulla ja eluga edasi minna.

\section{Kõhukasvataja lugu nr 10}

Õnnelik sain olla kuni 17. rasedusnädalal tulid järsku ära looteveed. [---] Ei saa eelmisest rasedusest üle, samas tahaks juba uut, et kergem hakkaks, aga kahjuks kõik on lootusetu. Kindlasti on teisigi sarnaste lugudega inimesi. Kuidas olete üle saanud? Kas ikka üritate uuesti (mina saan teha seda umbes aasta pärast) või loota, et ajaga läheb lein väiksemaks ja jäädagi kahe lapsega, kes on juba suureks kasvatatud [---]. Praegu ei suuda ma küll selle peale mõelda, et ma kunagi pesamuna ei näe. 


\section{Ivf-ka lugu nr 16}

Ka mina olen selle jubeda kogemuse läbi elanud. Minul oli IVF rasedus, vanust oli 38 kui ühel hetkel 17+ nädalal tulid veed ja järgnes kõik samamoodi kui sul. [---] Kirjutasin kohe samal ööl IVF arstile, et soovin nii ruttu kui võimalik saada uuele katsele. Sellele järgnes kaks ebaõnnestunud katset. Ja siis kuu enne kui sain 41 (haigekassa maksab kuni 41 aastani) õnnestus mu katse. [---] Lõpuks sünnitasin imearmsa tütrekese $38+1$, kes on juba 8 kuune. [---] Palun proovi tagasi saada oma tasakaal ja koosta endale nn tegevusplaan. Lase need kurvad mõtted ja tunded lahti. See võtab aega, midagi pole teha.

Kui vähipatsientide gruppe internetis vaadelnud uurijad on täheldanud, et sealsed osalejad võivad oma lugu jagada, et kuulda saatusekaaslastelt nn ellujäämise lugusid (Terp Høybye \& Johansen \& Tjørhøj-Thomsen 2005: 214-215), siis Perekooli Rasestumise, Lapse ootamise ja Sünnituse foorumeis võib oma lugu jagav naine paluda vastutasuks nn edulugusid või õnneliku lõpuga lugusid. Kirjeldatud aspekti ning asjaolu, et naised ammutavad teiste lugude lugemisest lohutust ja jõudu, näitlikustab järgnev tsitaat triibupüüdja loost, millel endal veel õnnelikku lõppu ei ole.

\section{Triibupüüdja lugu nr 42}

Ma ei tea isegi täpselt, mida siit foorumist ootan... Võibolla on mul lihtsalt vaja jälle kõik see endast välja kirjutada, et leida jõudu edasi minemiseks...Vanust küll alles 24 (peagi 25), kuid meditsiiniline ajalugu kirju. Oleme mehega jätkuvalt oma esimest beebit \”pü̈̈mas\”. Üle elatud kolm peetumist, iga järgnev pisut hilisemas järgus. Arstide/geneetiku poolt läbi ja lõhki uuritud / puuritud ning terveks tunnistatud... Ega praegu muud polegi, kui edasi proovida. Kui keegi on kunagi sarnases olukorras olnud, siis suurima heameelega loeks edulugusid! See annaks tohutult jõudu!

Edulugusid kirjutatakse Perekoolis rasedust planeerivate ja last ootavate naiste suhtluses nii reageeringuna foorumikaaslaste abipalvetele kui ka lihtsalt soovist teistele oma looga lootust sisendada. Nii soovivad naised, kes on varasemalt leidnud lohutust ja tuge teiste lugude lugemisest, pakkuda sama ka teistele. Seda et naiste esmaseks ajendiks oma lugu jagada võib olla lihtsalt soov teisi aidata, näitavad järgnevad katkendid korduvaid raseduste peetumisi ning katkemisi kogenud naiste lugudest. Mõlema naise teekond lapse sünni ehk "imeni" on olnud väga raske. Esimene autor on saanud aastaid viljatusravi ning elanud üle kuus raseduse peetumist/katkemist, teisel naisel ei õnnestunud kehavälise viljastamise teel rasestuda üle kolme aasta. Siiski on neil lugudel õnnelik lõpp. Naised on viimaks emaks saanud ning usuvad, et nende kogemus võiks olla 
rühmakaaslastele innustuseks ja julgustuseks - kui nemad jõudsid oma "ime" ära oodata, küllap õnnestub lapsesaamine ükskord ka teistel.

\section{Triibupüüdja lugu nr 22}

Lubasin kord endale, et kui minu lool on õnnelik lõpp, siis jagan seda inimestega, sest mäletan, et omal ajal otsisin nii väga seda tuge ja et oleks kuskil keegi, kel samas olukorras on olnud, õnnelik lõpp. Et oleks lootust. Seega, ma loodan, et ehk on kellelegi abiks või toeks. [---] Seega minu lugu on tõestuseks - ei tasu alla anda!

\section{Ivf-ka lugu nr 1}

Kirjutan pisikese eduloo neile, kes võibolla tunnevad, et ei jaksa enam proovida ja loota. Olen üritanud rasedaks jääda juba väga mitmeid aastaid, edutuid ivf-e üle 3 aasta ja lugematu arv (8-9 kindlasti), vahetasin arste, jooksin hiina nõelravi vahet jne. Seda, mis tunnet tekitab iga ebaõnnestunud ivf, ei ole mul vaja kellelegi seletada. [---] Aga ikkagi proovisin ja proovisin, mõtlesin, et teen seda niikaua kuni vanus lubab ehk siis haigekassa maksab. Ja siis ta tuli... märtsis helistas arst ja teatas lõpuks hea uudise! Algul oli hirm ikka [---] Aga ei, beebi kasvas ja detsembri algul sündis mulle poeg, olin just saanud 40, ja jõudsin oma ime ära oodata! Seega jõudu kõigile proovimiseks, teie beebi tuleb teie juurde just enda poolt valitud ajal!

\section{Infovahetus ja nõuanded}

Perekooli foorumeisse kirjutatud kogemuslugude ja nendega seotud kommentaaride analüüsist tuleb esile, et sageli on just kogemuslugude kirjutamine ja teiste lugude lugemine see, mille tõttu saavad naised teadlikuks ühest või teisest enda seisundit puudutavast aspektist, mis ajendab küsimusi esitama ja täiendavat infot hankima.

Teiste naiste kogemuslood internetirühmas võivad olla oluliseks alternatiivseks või lisainfoallikaks sellele, mis saadakse arstidelt vm meditsiinipersonalilt. Lugudest ja foorumiliikmete tagasisidest ilmneb, et spetsialisti vastuvõtt kestab tavaliselt suhteliselt lühikest aega ning seetõttu ei pruugi vajalike protseduuride järel jääda seda hetke, et naine saaks esitada täiendavaid küsimusi või rääkida kõigest, mis talle tema seisundiga seoses muret teeb. Nii saadakse teiste kogemuslugudest infot, mida tähendab näiteks triple test (s.o raseda veeniverest tehtav uuring, mis näitab geneetiliste haiguste riske ja neuraaltorudefekte) või missuguseid tingimusi pakub üks või teine haigla sünnitamiseks (tasuline ämmaemand, vettesünnitus, erinevate sünnitusvalu leevendavate abivahendite 
olemasolu jm). Niisamuti näitavad foorumikommentaarid, et teiste kogemuslugudest saadud info võib aidata naisel valmistada ette küsimusi, mida esitada järgmisel kohtumisel ämmaemanda või arstiga (vrd Terp Høybye \& Johansen \& Tjørhøj-Thomsen 2005: 215).

Naine võib ka nimelt eelistada info hankimist teiste poolt foorumisse kirjutatud kogemuslugudest, sest kardab spetsialistide ees rumalana näida, konkreetne teema valmistab talle piinlikust, või tunneb ta, et ei leia meditsiinipersonaliga ühist keelt. Viimati mainitud põhjendusi nimetavad teiste kogemuslugudest info otsimise ajendeina näiteks endometrioosi põdevad naised. Lugudest ja nende tagasisidest tuleb esile, et diagnoosi teadasaamine on olnud nii mõnelegi naisele šokk, sest puudusid vastavad eelteadmised ning arsti selgitustest jäi mulje justnagu oleks nende võimalused last saada minimaalsed või olematud. Seevastu teiste sarnaste kogemustega naiste lugudest on saadud täiendavat, lootust sisendavat informatsiooni nii ravivõimaluste kohta kui ka tõendeid elust enesest, et endometrioosi diagnoosiga naistel on siiski võimalik viljastuda ja lapsi sünnitada. Järgnevad tekstilõigud pärinevad endometrioosi põdevate naiste kogemuslugudest. Esimeses näites kirjeldab autor diagnoosi saamise hetke, sellega seotud negatiivseid emotsioone ja suutmatust arsti sõnu mõista, ning julgustab saatusekaaslasi mõtteid ja kogemusi jagama. Teine lugu on kirjutatud vastusena esimesele loole. Selles loos kirjeldab autor sarnast kogemust, jagab infot, millest ta enda diagnoosi puhul abi leidis, ning innustab internetirühmakaaslasi oma unistuste nimel võitlema.

\section{Triibupüüdja lugu nr 2}

[---] Huvitavad saatusekaaslaste mõtted seoses selle haigusega. [---] Endal tuli kuidagi ootamatult see kõik, kunagi polnud probleeme päevadega ja vaevustega nende ajal. [---] nii ma siis aasta tagasi LAP-il käisin ja endometrioosi II astme diagnoosi sain, arsti sõnad olid kuidagi nii negatiivse alatooniga, et peale nutmise ma ei osanud kuidagi reageerida, seda enam, et polnud endal aimugi, mis asi see endometrioos on ja miks mul see on. Arstid võiks kuidagi inimese keeles rääkida need asjad selgeks, aga mulle öeldi suhteliselt konkreetselt, et paar aastat ja siis jääb vaid kunstlik viljastamine. [---]

\section{Triibupüüdja lugu nr 4}

[---] Arst ei andnud mulle ise rasestumiseks mitte mingit lootust, mäletan, kuidas arst veel ütles, et te ei saa MITTE KUNAGI LAST, see lause viis mu endast väga välja, nutsin ohjeldamatult [---]. Lõpuks võtsin enda kokku ja tegin esimese sammu viljastusarsti juurde. Tuli oodata pikalt enne kui sai alustada IVF katsetega. Kuid hetkel ma ei kahetse ühtegi oodatud minutit ega ühtegi negatiivset rasedustesti, olen õnnelik, et mul 
IVF lõpuks õnnestus ja ootan enda esimesi lapsi. [---] soovin kõigile jõudu ning jaksu võitlemisel oma unistuste nimel!

Eelnevale näitele sarnaselt täidab suur osa käesolevas käsitluses vaatluse all olevaid kogemuslugusid omamoodi mitteametliku nõustamise funktsiooni selles mõttes, et kui arstid räägivad enamasti neile teadaolevatest faktidest, siis nende naiste lood, kel on endal olnud raskusi rasestumisega või kes on kogenud rasedust või sünnitust, võimaldavad ligipääsu teistsugusele vaatepunktile - need kõnelevad lugejale sellest, kuidas miski on tegelikult toimunud ja tundunud, ning milleks tuleks naisel valmis olla (vrd ka Marander-Eklund 2000: 417; Wright \& Bell 2003: 44). Näiteks ilmneb kogemuslugudele antud tagasisidest, et need võivad aidata vähendada hirme (anda vastuse küsimusele, kas see, mis minu kehaga toimub, on ikka normaalne vm), olla abiks otsuste tegemisel (nt millist viljakusravimeetodit eelistada või milliseid abivahendeid kasutada sünnitusel) või aidata valmistuda olukordadeks, kus tuleks enda eest seista (nt lootevete avamine sünnitusel kui rutiinne toiming vm) (vrd Cohen \& Raymond 2011: 944-945; Kaliarnta \& Nihlén-Fahlquist \& Roeser 2011: 286; Malik \& Coulson 2008: 109).

Kui lugeja võib leida infot ja nõuandeid teiste kogemuslugudest, siis võib ka kogemusloo kirjutaja enda esmaseks sihiks olla soov pakkuda teadmisi ja nõu teistele. Ühtlasi võib naine jagada oma lugu selleks, et saada ise täiendavat informatsiooni või nõuandeid. Nii võib ühelt poolt olla ivf-ka loo näol tegu detailse ülevaatega naise haigusloost - kuidas kehavälise viljastamise otsuseni jõuti, missuguseid protseduure kui pika perioodi jooksul läbiti, milliseid ravimeid manustati ja millised olid tulemused. Sellise info võib autor suunata neile, keda IVF veel ees ootab, et pakkuda ülevaadet selle protseduuri olemusest. Teiselt poolt võib ivf-ka lool internetirühmas olla arutelu algatav otstarve, mille sihiks on enda viljatuse või ebaõnnestunud raseduste põhjuste väljaselgitamine ning parima võimaliku raviviisi leidmine (vrd ka Cohen \& Raymond 2011: 937). Ühe sedalaadi tekstiga on tegu järgneva näite puhul, kus autor pikib oma IVF-teekonda vahendava loo sisse järjepanu saatusekaaslastele suunatud küsimusi enda seisundi ja võimalike edasiste tegutsemisstrateegiate kohta.

\section{Ivf-ka lugu nr 10}

Tere minu poolt, panen ka siia oma esimese tervikloo [---] Kõik algas novembri lõpus tegelikult juba, kui saime teada, et mehel on väga, väga vähe seemnerakke. [---] KÜSIMUS - kas laseksite ikkagi ka endale täpsemad uuringud teha? Pean silmas laparoskoopiat jms uuringuid? Milliseid täpsemalt? Kogemusi? [---] Alustasin ravi Brimocriptiini tablettidega juba umbes maikuu alguses, sest prolaktiini tase oli kõrge, lausa 1000. See langes, aga siis süstid, mida hakkaksin süstima, tõstsid taseme jälle 
ülikõrgeks [---]. KÜSIMUS - kas on ka teistel olnud see tase kõrge? Olen uurinud ja googeldanud ja püüdnud arstilt vastuseid saada, aga siiski täpselt pole aru saanud, mida see tase mõjutab? Kogemusi? [---]

Perekooli foorumisuhtluse vaatlusest ilmneb ka, et oma kogemuse, sellega seotud sündmuste ja emotsioonide detailne kirjeldamine võimaldab loo kirjapanijal saada rühmakaaslastelt spetsiifilisemat tagasisidet ja nõu otsuste tegemisel, kui seda võimaldab üksnes fakti nentimine ja küsimuse esitamine. Näitena võib tuua lapseootajate keisrilõiget puudutavad teemapüstitused. Kui foorumiliige üksnes nendib fakti, et ei soovi loomulikul teel sünnitada ning palub nõu, mis teised sellest arvavad, jääb ka tagasiside enamasti niisama lakooniliseks, päädides näiteks pelgalt rühmakaaslaste tõdemusega, et "sa ei saa seda ise valida". Seevastu kogemuslugude puhul, mis avavad asjaomast tausta, on tendents, et ka tagasiside on niisama sisutihe kui lugu ise. Järgnevas loos seob autor soovi sünnitada oma teine laps keisrilõike abil oma esimese traumaatilise sünnitamiskogemusega. Oma tahet põhjendab ta asjaoluga, et vaatamata ettevalmistustele ei suutnud ta sünnitusel oma keha kontrollida, ning selle tulemusel tekkisid sünnitushirm ja depressioon. Selle loo detailidele tuginedes ja teades, mis on teemaalgataja soovi taga, näitavad loo lugejad tema suhtes enamjaolt üles mõistvat suhtumist. Isiklikele kogemustele toetudes ja vastukaaluks enda lugusid jagades avaldatakse arvamust, miks võis loo kirjapanija esimene sünnitus nii halvasti lõppeda. Niisamuti arutletakse, kuidas võiks naine teine kord toimida, et sarnast situatsiooni vältida, kuid siiski loomulikul teel sünnitada. Näiteks pakub üks rühmakaaslane enda sünnitustele viidates, et oma lugu jaganud naise esimene sünnitus võis olla raske vete avamise tõttu. Rühmakaaslast ennast on aidanud sünnitoetaja, refleksioloogia ja homöopaatia, ning soovimata teemaalgatajat ümber veenda, on need tema arvates siiski võimalused, mida tasub kaaluda.

\section{Kõhukasvataja lugu nr 39}

Algas kõik kuus aastat tagasi maikuus, kui sündis minu esimene poeg. [---] Kõik mida olin õppinud ja milleks olin ju 9 kuud ennast valmistunud oli kadunud. [---] See kõik sellepärast, et ma lihtsalt ei teinud koostööd. [---] See päev otsustasin ma sisimas, et ei iial enam. Mul oli meeletult raske paranemine. Mul oli kohutav depressioon, ma ei suutnud/osanud oma lapsest rõõmu tunda. [---] Aga nüüd [---] ootan oma teist poega. [---] Ma ei ela seda teist korda üle, mul on surmahirm. [---] Ma soovin saada keisrilõiget. [---] Ma ei julge enam proovida, et äkki seekord ma suudan ennast ohjata ja ei lähe paanikasse. Sest äkki on just vastupidi äkki ma seekord panen oma lapse veel suuremasse ohtu, mis siis saab? 


\section{Sünnituslugu $\mathrm{nr} 2$}

[---] Ma ise selle loo lugemise järgi arvaks, et äkki oli probleem vete avamises? Mul endal üks sünnitus, kus veed ise puhkesid ja teine, kus veed avati (sünnituse esilekutsumiseks, kui tuhusid üldse polnudki). Teine oli ikka meeletult valus võrreldes esimesega. [---] Mind päästis teisel sünnitusel sünnitoetaja kohaolek. Sünnitoetaja aitas mul tuhudega toime tulla, kasutas selleks minu toetamist nendes asendites, mida ma soovisin võtta, refleksioloogiat (vajutas mingeid punkte) ja homöopaatiat. Refleksioloogiast oli küll väga otseselt kasu. [---] Ma ei soovinud sellega sind ümber veenda. Lihtsalt võimalusi, mida veel uurida / mõelda.

\section{Hoiatus}

Mõnikord on foorumisse kirjutatud rasestumist, lapse ootust või sünnitust puudutava kogemusloo näol tegu hoiatusega (vrd Kõiva 2010: 245; Reinaus 2007: 19, 87). Muude nõuandvate kogemuslugude hulgas eristuvad hoiatuslood Perekooli foorumeis selle poolest, et neis suunatakse teisi foorumiliikmeid üht või teist situatsiooni või teguviisi vältima. Sõnum kaaskannatajatele on: see juhtus minuga, palun hoiduge sellest.

Kui Barbara F. Sharf (1997: 71-72) on rinnavähile keskenduvate internetirühmadega seoses märkinud, et seal arutletakse muuhulgas arstide ja patsientide suhete teemal - näiteks võib sealt leida kaebusi, et arst ei hoiatanud patsienti olulistest ravi kõrvalmõjudest ja põhjustas nii tüsistusi - siis võib sarnast temaatikat täheldada ka last saada soovivate, rasedate või juba sünnitanud naiste kogemuslugudes. Viimased kannavad nii mõnigi kord sõnumit, et tulevane ema ei peaks arste ja ämmaemandaid pimesi usaldama. Näiteks on järgneva teksti autorit ajendanud foorumis oma lugu jagama tõik, et ämmaemand saatis ta triple testi tegema liiga vara, ning seetõttu ei ole selle tulemus usaldusväärne. Naine nendib, et sel põhjusel tuleb tal kuni looteveeuuringuni muretseda, kas lapsega on ikka kõik korras. Loo lõpus suunatakse lugejaid arstide ja ämmaemandate tegevust hoolikamalt jälgima ja ise enda eest seisma - selleks, et teised tulevased emad ei peaks samamoodi muretsema nagu loo autor.

\section{Kõhukasvataja lugu $\mathrm{nr} 38$}

Tänan teid kõiki oma lugude eest! [---]. Arvan, et arstid on ikka hooletud küll. Ämmakas saatis mu triple testi tegema liiga vara (nädalate järgi). Viimase uh järgi oli küll 15+2 täis triple testi ajaks, kuid kuna ma tean täpselt, millal toimus viljastumine, siis tean ka seda, et siis oli hoopis 
14+2. Rääkisin sellest ämmakale, kes väitis et ei, kõige täpsem on ikka viimane UH. No nii. Aga triple testis on üks asi, mida mõodetakse koorion-gonadotropiin ( $h C G$ ). Selle väärtus on ikka väga erinev, olenevalt sellest, mitmes nädal on [---] No ja kui lisada siia veel minu vanus (35), siis tulebki juba kõrgem downi risk. Pika jutu kokkuvõtteks - jälgige ja kontrollige oma arste, ämmakaid. Nad on hooletud või noored või kogenematud ja siis kannatate teie. Muidugi ei saa ma ikkagi rahu enne kui looteveeuuring tehtud ja vastus käes. Muretsen nüüd järgmised ca kuu aega selle asemel, et rasedust nautida.

Puudulik dialoog meditsiinipersonaliga ning sõnum, et naised peaksid enda eest seisma, on foorumist lohutuse ja abi otsimise kõrval üks ajendeid oma loo kirjapanemiseks ka lapse kaotanud naistel. Järgnevad tekstikatked pärinevad kaheksandal raseduskuul lapsest ilma jäänud naise loost, kes pöördus jalgade tursega haigla erakorralise meditsiini osakonda. Vaatamata sellele, et analüüsid ei olnud korras, saatis valvearst naise koju ja palus hommikul tagasi tulla. Laps sündis surnult, kuid hiljem väitsid teised arstid, et kui valvearst oleks jätnud naise kohe haiglasse ja teinud keisrilõike, oleks see lapse elu päästnud.

\section{Kõhukasvataja lugu nr 1}

Ma tunnen, et pean teiega jagama oma kurba saatust. Nimelt olin ma [---] 8. kuud rase, ootasin pisipoega. Miks ma teile seda räägin on sellepärast, et keegi teine ei peaks seda läbi elama. [---] istusime mehega seal palatis pool päeva, keegi ei tulnud meie juurde, et rääkida, mis tegelikult toimub [---] lõpuks läks mees ise [---] arst vastas selle peale sedasi, et kas te siis ei teagi, et te naine sünnitab küll, aga see laps enam ei ela, mees küsis arstilt, et aga mis ma naisele ütlen, arst oli öelnud ärme täna ütle midagi, et te naine täna nagunii ei sünnita. [---] lõpuks, kui lapse ära sünnitasin, tuli välja, et lapsel oli nöör ümber kaela ja sellest tekkis tal hapniku puudus. Teised arstid ütlesid, kui oleks valvearst jätnud haiglasse ja teinud keisri, oleks see lapse elu päästnud.

Teine käesoleva uurimuse tulemusel eristunud rühm hoiatuslugusid on seotud naiste endi eksimuste, mõtete ja tunnetega, mida soovitatakse teistel foorumiliikmetel vältida. Näiteks on mõned kogemuslood suunatud neile foorumilugejaile, kes pole oma lapsesoovis kindlad või soovivad aborti teha. Nende lugude keskmes on loo autori emotsioonid seoses abordi, raskustega rasestumisel või ka lapse kaotusega. Järgnevas tekstikatkes kirjutab autor raseduse katkemisega seotud hingevalust, pannes neile, kes oma lapse soovis kahtlevad, südamele, et nad mõtleks otsust langetades neile, kes on oma lapse kaotanud. 


\section{Kõhukasvataja lugu nr 15}

Kuna pean üheks parimaks eneseväljenduse viisiks kirjutamist, siis panen oma mõtted kirja kõigile neile lugemiseks, kes tunnevad sama mida mina. Hingevalu [---] Meie beebi südametöö lõppes 8+3 nädalal. [---] Nii, et kõik, kes te kardate või ei oota oma beebit nii väga. PALUN TEHKE SEDA! [sünnitage] Mõelge korraks nende inimeste peale, kes on üle elanud kaotuse, mida ei anna võrrelda millegagi. Hinnake, et teie sees kasvab pisike ime ja tundke sellest rõõmu.

Oma loo kirjapanemise sihiks võib olla ka lihtsalt hoiatada rühmaliikmeid liigse muretsemise ning ise endale diagnoosi panemise eest. Nii märgib kahest järgnevast näitest esimene autor, et lapsesaamise soovil ei tohi lasta kujuneda kinnisideeks, sest liigne muretsemine võib anda hoopis vastupidise efekti. Teise loo autor jagab saatusekaaslastega kogemuslugu sellest, kuidas ta internetist leitud info põhjal arvas, et tema rasedus on läbi, kuid tegelikult hukkus üks loode kaksikrasedusest.

\section{Triibupüüdja lugu nr 35}

[---] Minu lugu ulatub 10a tagusesse aega [---] Käisin arsti juures ja tuli välja, et mul on polütsüstilised munasarjad [---]. Arst, kes oli tolle aja väga kõva sõna, tõdes, et ega ma loomulikul viisil ei saagi lapsi. [---] Ma lasin mõttest ja soovist lahti. Mõtlesin, et kui laps tahab loomulikult tulla, siis ta ka tuleb. Ja oh imet, ühel päeval nägin oma esimesi triipe. [---] Õnn kestis 2 nädalat. [---] Minu tüsistused olid rasked. Sisemuses ma tundsin, et kui üks, siis tuleb veel! Ja nii tuligi. [---] Sündis meie kauaoodatud lapsuke. [---] Natuke vähem kui 2 a pärast sündis teine, veel 2aasta pärast kolmas! [---] Oma looga tahtsin ma öelda, et kunagi ei tasu kaotada lootust, aga lapse saamine ei tohi olla ka kinnisidee, sest see pärsib saamist kohe kindlasti! Jõudu ja jaksu kõigile triibutajatele.

\section{Triibupüüdja lugu nr 41}

[---] uurisin ja lugesin googeldades vastavat teemat, panin vaimu valmis kõige kurvemaks stsenaariumiks. [---] valutasin terve õhtu [---] Jätsin mõttes lapsega hüvasti. [---] Lõpuks sain arstile. [---] Seal selgus, et olen rase mis rase. [---] Tagantjärgi tarkus - ootasin kaksikuid, üks lootehakatis hukkus ja väljus, teine on elus. [---] Tänases infoühiskonnas saab ennast lausa neti teel diagnoosida, aga samas on igas loos alati erandeid. Olin valmis kõige halvemaks, aga läks hoopis niimoodi. [---] 


\section{Eneseesitlus}

Üks ajend internetirühmades osalemiseks on soov olla märgatud. Oma loo jutustamine võimaldab teha ennast teistele nähtavaks ja paigutada end maailmas mingile kohale. Nõnda tegelevad ka naised, kes jagavad oma kogemuslugusid pere- ja terviseteemalistes internetikeskkondades, eneseesitluse ja identiteediloomega (vrd Boer \& Slatman 2014: 17-25; Kõiva 2009: 172; Orgad 2005: 3; Reinaus 2007: 41-43, 87-88; Terp Høybye \& Johansen \& Tjørhøj-Thomsen 2005: 214; Toscano \& Montgomery 2009: 1016).

Eneseesitlusel ja identiteediloomel võib internetifoorumisse kirjutatud kogemuslugude puhul olla erinevaid väljundeid. Mõnikord võivad foorumikasutajad petta oma tausta või identiteedi osas - see tähendab, et kogemusloo vormis kirjutatud teksti taga ei pruugi olla see isik, kellena ta end esitleb ning ka loos kirjeldatavad kogemused ja sündmused ei pruugi olla tegelikkuses aset leidnud. Perekooli foorumitega seoses on sedalaadi juhtumeid fikseerinud Reeli Reinaus. Oma sünnituslugude ja eneseesitluse teemale keskenduvas magistritöös vaatleb ta muuhulgas paari näidet fiktiivsest eneseloomest, see tähendab juhtumitest, mille puhul ilmnes, et foorumisse kirjutatud lugude puhul oli tegu väljamõeldud isikute, sündmuste ning kogemustega (vt Reinaus 2007: 46-49 Birgith ja Kalla ning Verbatimi juhtumid). Käesoleva uurimistöö jooksul ühtegi fiktiivse eneseloome juhtumit ei tuvastatud. Siiski tuli identiteediloome ja eneseesitlus kui üks rasestumise, lapseootuse ja sünnitusele keskenduvate lugude funktsioone internetirühma suhtluse seisukohast ning laiemate tähenduste loomisel olulisena esile.

Nii triibupüüdjate, ivf-kate, kõhukasvatajate kui ka sünnitanud naiste lood Perekooli foorumeis peegeldavad seda, kes on kirjutaja, ning kuidas ta rasestumise, lapseootuse või sünnitamise kogemustega toime tuleb. Teisisõnu toimivad isiklikel kogemustel põhinevad jutustused internetirühmas eneseesitlusena selles mõttes, et need loovad naisest pildi kui sünnitajast, emast vm (vrd Marander-Eklund 2000: 432). Ühtlasi võimaldab kogemusloo kirjutamine naisel näidata, mil viisil suhestub tema isik ja tema kogemus teiste foorumikasutajatega ning kinnitada enda kuuluvust just ühte või teise siserühma - on need siis pikaaegsed rasestuda soovijad, kehavälise viljastamise protseduuri läbivad või sünnituse kogemusega naised. Nii on konkreetse siserühma suhtluse raames ühel isikul vaid üks tähenduslik "minu lugu" - see on üks ja seesama kogemuslugu pikaaegsest lapsesoovist, lapseootusest, viljatusest või sünnitusest, mille ümber keskendub suhtlus rühmakaaslastega.

Perekooli foorumite suhtluses toimivad naiste kogemuslood kui visiitkaardid, mille abil on võimalik ennast teistele tutvustada ja kontakte luua. Näiteks võib enda loo jagamine olla vaikimisi mõne siserühmaga liitumise eelduseks. 
See tähendab, et enne, kui uustulnuk rühma suhtlusesse aktiivsemalt sekkub, kirjutab ta alustuseks oma loo, mis on omamoodi viisiks öelda: "Tere!" Ühe sedalaadi tekstiga on tegu järgneval juhul. Selles teatab autor, et liitub beebiootajate kommuuniga ning kirjeldab, kuidas ta rasedus seni on kulgenud.

\section{Kõhukasvataja lugu nr 31}

Tervitused kõigile beebiootajatele! Mõtlesin, et liitun ka siinse toreda kommuuniga. Hetkel rasedust 7+1 nädalat, südame oleme ära näinud ja tundub, et pisike kasvab jõudsalt. Vähemalt und ja toitu nõuab juba minu kaudu üsna tublisti. [---] Alguses oli meil hirm ka. U 5ndal nädalal viibisin välismaal ja ärkasin öösel kohutava kõhuvalu peale. [---] Õnneks kokku kestis see vb 15 minutit, siis hakkas vaikselt järele jääma. Kuna pidin veel välismaal poolteist nädalat olema, siis see oli päris jube aeg. Ma ei osanud seal minna suvalise arsti juurde [---] Nii väga muretsesin, kas kõik on ikka korras. Seega siinkohal ma natuke üritan lohutada ka neid, kes samas olukorras on olnud, et kui on jube valu ja ei tea, mida see tähendab. Arst ütles lõpuks, et see tekib paljudel naistel siis, kui peaks olema järgmine ovulatsioon. Põhjust, miks see nii valulik on, täpselt ei teatagi. Igal juhul meil on senimaani kõik hästi läinud :) Loodan, et ka kõigil teistel mured laabuvad :)

Kogemuslugu võib olla ka vahendiks, mille põhjal rühmaliikmed naise teiste seast ära tunnevad. Perekooli liikmed saavad suhelda ja jagada oma lugusid foorumis nii kasutajanimede kui ka anonüümsele kasutajale viitava pseudonüümi Kägu all. Siiski etendavad eneseesitlusel ning selgitamisel, kes on kes, olulisemat rolli kogemuslood - neis kirjeldatud kogemused, sündmused, kuid ka konkreetse isiku kirjutamisstiil. Nimelt on Perekooli Rasestumise, Lapse ootamise ja Sünnituse alafoorumeis kohtuvatele siserühmadele iseloomulik, et rühmaliikmeid võidakse ära tunda nende lugude põhjal olenemata sellest, kas nad osalevad suhtluses anonüümse Käona või kasutajanime all. Näiteks võib ühelt poolt keegi anonüümsele teemaalgatusele ja loos kirjeldatud detailidele reageerides vastata: "Ma tean sind, ma olen sinuga ühes teises teemas kokku puutunud." Teiselt poolt võib kasutajanime all esinev foorumiliige kommenteerida kellegi teise lugu, nentides, et ta ei hakka ise enda lugu kordama, "sest te kõik nii ehk nii teate seda".

Võib öelda, et sedalaadi foorumid nagu Perekool annavad lapse saamise sooviga ning lapseootuse- ja sünnituskogemusega naistele avalikkuse silmis hääle. Sealseid tekste lugedes saavad foorumi külastajad aimu, millised on kaasaja naiste probleemid ja kogemused seoses lapseootuse ja sünnitusega. Nii on Perekooli vestlusringide sagedasteks külalisteks näiteks ajakirjanikud, kes sealt aktuaalsemad teemad välja nopivad, neist kirjutavad ning teema- 
kohaseid avalikke arutelusid tekitavad. Seoses kirjeldatud aspektidega ning eneseesitluse kui ühe lugude jutustamise funktsiooniga tasub vaatlusaluste kogemuslugude puhul peatuda küsimusel, kuivõrd on need tegelikult kirjutajate endi vaatepunktist mõeldud enese ja oma kogemuste presenteerimiseks laiemale avalikkusele. See küsimus on oluline, sest rasestumisele, lapseootusele, kehavälisele viljastamisele ning sünnitusele keskenduvate lugude puhul on vastuolu nende sisu ja ligipääsetavuse vahel - nimelt on need naiste isiklikul elul põhinevad, delikaatseid seiku, kehalisi kogemusi ja meditsiiniprotseduure vahendavad lood internetiotsinguga kergesti leitavad ning nende lugemiseks ei pea ennast isegi keskkonna kasutajaks registreerima.

Perekooli alafoorumite suhtluse analüüsist ilmneb, et enamasti ei ole sealsed kogemuslood, iseäranis triibupüüdjate ja ivf-kate lood, ligipääsetavusele vaatamata mõeldud auditooriumile väljaspool konkreetset internetirühma, vaid need on suunatud teistele rasestuda soovijatele, lapse ootajaile ning sünnitajatele. Sama fenomeni on täheldanud pisut teistsuguses kontekstis Shani Orgad (2005: 145) nentides, et kuigi internetisuhtluses osalejad teadvustavad sealsete keskkondade avalikke dimensioone, võidakse siiski käsitleda enda suhtluskeskkonda privaatsena ning oma lugusid isiklikena. Teisisõnu: kuigi kindlasti on ka erandeid, ei räägita oma lugu enamasti selleks, et laiem avalikkus võiks konkreetsest isikust ja tema loost teada saada. Pigem on Perekoolis täheldatav vastupidine tendents - ei soovita avalikkuse ees siduda oma lugu ja isikut ning anda sellega kõneainet väljaspool konkreetset internetirühma. Seda illustreerivad arutelud, milles foorumiliikmed avaldavad pahameelt ajakirjanduses ilmunud artiklite üle, kus on kasutatud foorumist kopeeritud materjale, või teemapüstitused, kus ajakirjanik üritab leida isikuid, kes oleks nõus oma lugu laiema avalikkusega jagama. Viimasega seoses võib tuua näite üleskutsest, kus sooviti leida naisi, kes oleks nõus ajakirjaveergudel jagama oma lugu lapsesaamisest viljatusravi või kunstliku viljastamise teel. Foorumisse kirjutatud tagasiside sellele üleskutsele oli valdavalt keelduv. Nii nagu võib lugeda järgnevatest tekstikatketest, ei soovitud oma lugu jagada, sest kardeti vääriti mõistmist või hukkamõistu. Samuti taheti kaitsta oma lapsi või põhjendati keeldumist sellega, et tahetakse palju muret põhjustanud peatükk oma elust kustutada ja eluga edasi minna.

\section{Tagasiside üleskutsele jagada ivf-ka lugu ajakirjanikuga}

Kommentaar nr 530: Sama siin, ei ole nõus oma raskest teest avalikult rääkima. Miks häbeneme? Sest et tahan kaitsta oma lapsi. Kunstlik viljastamine on enamike inimeste jaoks tundmatu teema ja tume maa, kuid eestlaslikult omaselt ollakse valmis kohe hukka mõistma. Mina ei taha, et minu lapsi mingiteks \“kunstlasteks\” nimetatakse, sellepärast pildiga ajalehte - never ever. 
Kommentaar nr 539: Ei, IVF pole surmapatt. Mina aga olen selle peatüki oma elust kustutanud, kuna see ei ole praeguses kontekstis enam oluline. Mul on toredad 3-aastased kaksikud, kelle saamislugu on meie kahe lugu. See on nii isiklik, et ma ei kavatse ka oma lastele kunagi rääkida midagi rohkem, kui et nad sündisid väga suurest armastusest. Üks inimene märkis tabavalt, et kommentaarid [on halvustavad]. Jah, just. Mistahes lugu IVF-iga saadud lastest või üldse sel teemal ja sinna tuleb tohutult kommentaare ajukääbikutelt stiilis \“miks on vaja kunstlikult lapsi treida \” jne. Aga kui keegi tahab väga oma perekonna intiimseid saladusi jagada, siis lasku käia.

\section{Ajaviide}

Keeruline on hinnata, kui palju on Perekooli kasutajaskonna seas neid, kes on seal oma lapseootuse või sünnituskogemuste tõttu ja palju on neid, kes käivad foorumit üksnes lugemas. Siiski saab kogemuslugudele antud tagasisidele tuginedes öelda, et mõlemal juhul võib teiste lugude lugemise üheks ajendiks olla lihtsalt aega veeta ja meelelahutust leida. Lisaks leidub kogemuslugusid, mille puhul võib öelda, et neil on ajaviiteline ja teistele meelelahutust pakkuv funktsioon ka nende kirjapanijatele endile (vrd Reinaus 2007: 89). Lugusid kirjutatakse, et lihtsalt teistega kogemusi võrrelda, selleks, et "ime ootus" kiiremini kulgeks, ning ka põhjusel, et internetirühmaliikmed, kellega end samastatakse, on oma loo kirja pannud. Nõnda on näiteks järgneval juhul tegu sellise sünnituslooga, mis on ajendatud tõsiasjast, et rühmakaaslane, kellega samaaegselt on last oodatud ja kogemusi vahetatud, on oma lugu foorumis juba jaganud.

\section{Sünnituslugu nr 30}

Kuna meil siin see ootamine ja sünnitusele minek olnud ikka [---] [nimetab rühmakaaslase kasutajanime] kõrvu ja võidu [---] ja tema tütre sünnilugu siin juba kirjas, siis ega meiegi saa kribamata jätta:D. Pole küll nii pikka ja pidulikku lugu võtta, aga no paari sõnaga siiski:).

[---] 28. ôhtul oli seljas imelik tunne ja määris veidike kahtlaselt [---] Mihklipäeva hommikul oli täitsa rahulik olla, aga veidi aega hiljem juba andis ikkagi selg tunda ja sikutas pisut ka kõhus, natukese aja pärast kordus ja nii hakkaski korduma :D. [---] lõunaks oli tegevus nii 5-7 minuti tagant-selga mõningane valu ja kõht sikutas kokkupoole. Ei midagi hullu üldse, aga arusaadav, et midagi ikkagi toimub. Kell 15 seadsin sammud haiglasse [---] siis läks veel mõni ülivalus press uhhuutamisega üksteise otsa ja siis üks hääästi valus põletav rebimistunne [---] Pojake sündis 
täpselt 16.00. Ei ainumatki rebendit. Kaaluks oli $3676 \mathrm{gja}$ pikkust $50 \mathrm{~cm}$. [---] Tervitused meie poolt kõigile virtuaaltuttavatele:)!

Ühtlasi kirjutatakse oma lugusid foorumisse seetõttu, et sellest on kujunenud internetirühma argisuhtluses omamoodi kirjutamata reegel - on ootuspärane ja loomulik, et kui naine jõuab enda IVF-teekonna lõppu, rasestumine õnnestub või sünnib laps, siis jagab ta teistega oma lugu. Sedalaadi naiste rasestumise, lapseootuse või sünnituse kogemust kokkuvõtvad lood võimaldavad naisel väljendada enda rõõmu rasestumise, lapse ootusega seotud probleemidest jagu saamise või lapse sünni üle, tänada kaasteelisi ja meditsiinipersonali, talletada enda lugu tuleviku tarvis, kuid pakkuda rühmakaaslastele ka ajaviidet ja meelelahutust, mida nad on omal ajal leidnud teiste lugude lugemisest. Järgneva tekstilõigu puhul on tegu sünnituslooga, mis on postitatud foorumiteemasse, mis koondab lähedase sünnitustähtajaga naiste lugusid. Loo autor kirjutab, et teeb "kirjatööga otsa lahti" vastates nii rühma ootusele sünnituslugusid jagada. Ühtlasi on lugu pandud kirja humoorikas võtmes, pakkudes nii kaasteelistele meelelahutust (vt kommentaar nr 602).

\section{Sünnituslugu nr 29}

Teen siis kirjatöödega otsa lahti. [---] Kell 12.30 tehti esimene KTG ja see andis teada, et laps tunneb ennast suurepäraselt, aga emaka töö on enam kui tagasihoidlik. [---] Üks ämmakas teatas, et noh, esimeseks ehmatuseks piisab küll ja proovime homme uuesti (nimetan teda siinkohal Aeglaseks, sest temast tuleb edaspidi veel juttu). [---] KTG ruumi toodi ratastool. Ma ei soovinud sinna istuda, vaid ainult kõndida, aga Aeglane teatas, et see on arsti käsk ja miks ma vastu vaidlen. [---] Sünnitustoa asemel sõidutas ta mu hoopis minu palatisse, et asju kokku pakkida. [---] Õnneks tuli tuppa ka liftitädi [---] ja ta ütles, et ma tegelen nendega ise. [---] Kuid sünnitustoa asemel sõidutas Aeglane mu protseduuride tuppa. Küsisin, et miks me siia tulime ja ta vastas, et ma laseksin inimesel oma tööd teha. Ma tahtsin talle karjuda, et ta võiks lasta mul sünnitada [---]. Liftitädi tahtis mu tooli Aeglase käest ära võtta, aga viimane teatas, et kuhu siis nii kiire on [---] Viimaks ometi jõudsime sünnitusosakonda. [---] Ütlesin arstile, et ma nüüd sünnitan ja ta soovis, et ma viskaks voodisse pikali ja siis vaatame. Ma vastasin, et ma ei heida pikali, sest ma sünnitan [---] ja laps sündiski ära. Mees astus sünnitustuppa sisse, kui mulle poissi kõhu peale sätiti ja palju õnne sooviti. [---]

\section{Kommentaar nr 602}

Sa tegid tuju nii heaks praegu. Väga ilmekalt ja lahedalt kirjeldatud seiklus. [---] 
Viimaks tuleb ajaviide kui üks kogemuslugude kirjutamise ajendeid esile ka lugudest, kus autor selgitab, et tema jaoks ei ole konkreetne teema enam aktuaalne, sest ta on ammu sünnitanud, rohkem peret ei planeeri, kuid käib ikkagi aegajalt foorumit lugemas ja reageeringuna teiste lugudele oma lugu jagamas - kui tunneb, et tal on kellegagi sarnane kogemus ning tema loost võiks teistele abi olla.

\section{Arutelu}

Vastastikune lohutamine ja abistamine kogemuslugude kirjutamise ja lugemise funktsioonina tuli esile $86 \%$ analüüsitud kõhukasvatajate lugudest, $46 \%$ triibupüüdjate lugudest, $27 \%$ ivf-kate lugudest ning 5\% sünnituslugudest. Põhjuseks, miks kõhukasvatajate lugude hulgas on lohutuse ja abi otsimine ning teistele sama pakkumine niivõrd suurel määral esindatud, võib pidada, et nende seas on mitmeid lapsekaotuslugusid. Triibupüüdjate lugudes on kõnealuse funktsiooni puhul keskne leida jõudu või sisendada lootust rasestumise ja viljatusega seotud probleemidega toimetulekul. Sarnaselt triibupüüdjate lugudele on ivf-kate lugude hulgas mitmeid teistele lohutust ja tuge pakkuvaid edulugusid. See vähene vastastikune lohutamine ja abistamine, mis seostub sünnituslugudega, keskendub peamiselt sünnitamiskogemusest saadud negatiivsetele emotsioonidele.

Vastastikune infovahetus kogemuslugude jagamise funktsioonina tuli naiste poolt foorumisse kirjutatud kogemuslugude puhul esile $87 \%$ ivf-kate lugudest, $67 \%$ kõhukasvatajate lugudest, $54 \%$ sünnituslugudest ja $52 \%$ triibupüüdjalugudest. Ivf-kate lugude puhul tuleb infovahetus kõige enam esile seetõttu, et nende hulgas on mitmeid nn terviklugusid. Viimastes vahendatakse emotsioonideta ja detailselt erinevaid IVF-katseid ja nendega seotud meditsiiniprotseduure. Sihiks on anda saatusekaaslastele ülevaade kehavälise viljastamise protseduurist ja sellest, mida üks IVF-teekond endast täpselt kujutab. Kõhukasvatajate infovahetus keskendub lapseootusega seotud meditsiiniprotseduuridele, sünnituseks ettevalmistumisele ja lapsekaotusest tingitud leinast ülesaamisele. Sünnituslugudes ja tagasisides neile vahendatakse infot ja nõuandeid kasutatud sünnitusasenditest, valuleevendamise vahenditest ning lapse sünniparameetritest nagu kaal, pikkus ja lapse tervislikku seisundit hindav apgari hinne, kuid ka üldisemalt sünnitusprotsessis toimunust. Triibupüüdjate lugude puhul ilmneb kõnealune funktsioon eelkõige rasestumisega seotud probleemile sobiva ravi otsimises.

Erinevate siserühmade lõikes tuli hoiatus kogemuslugude funktsioonina esile $10 \%$ kõhukasvatajate lugudest, $7 \%$ ivf-kate lugudest, $5 \%$ sünnituslugudest 
ja 4\% triibupüüdjalugudest. Kuigi võrreldes teiste käesolevas käsitluses vaadeldud kogemuslugude funktsioonidega on hoiatus suhteliselt vähe esindatud, ilmnevad ühele või teisele siserühmale iseloomulikud teemad. Kõhukasvatajate lugudes ja sünnituslugudes manitsetakse naisi meditsiinipersonali mitte pimesi usaldama ja ise enda eest seisma. Seevastu triibupüüdjate ja ivf-kate lugudes hoiatatakse naisi nende endi mõtete ja tegevuste eest, mis võivad neile negatiivseid tagajärgi tuua. Näiteks on neis korduvad teemad liigne muretsemine, abort ja interneti abil enese seisundi diagnoosimine.

Eneseesitlus tuli foorumisse kirjutatud kogemuslugude funktsioonina esile 95\% sünnituslugudest, $87 \%$ ivf-kate lugudest $38 \%$ kõhukasvatajalugudest ja $29 \%$ triibupüüdjalugudest. Peaaegu kõigi sünnituslugude kohta saab öelda, et need toimivad internetirühmas eneseesitlusena seetõttu, et need peegeldavad ja tõstavad esile seda, kuidas naine sünnitusel hakkama sai. Nii ivf-kate, kõhukasvatajate kui ka triibupüüdjate lugude puhul tuleb eneseesitlus lugude kirjutamise funktsioonina esile seoses enda samastamisega sarnase kogemusega naiste rühmaga ("Mul on ka sarnane lugu", "Olen ka sama kogemuse üle elanud") kui ka seoses enda tutvustamisega rühmale ("Liitun ka siinse kommuuniga"). Huvitav on kõigi vaadeldud kogemuslugude puhul esile tulnud aspekt, et kuigi naiste poolt Perekooli foorumitesse kirjutatud lood on internetis kergesti ligipääsetavad, ei ole need enamasti mõeldud enese ja enda kogemuse esitlemiseks väljaspool konkreetset internetirühma, vaid üksnes naistele, kel on sarnane kogemus. Põhjusena, miks see nii on, võib tuua avaliku arvamuse, mis tihtilugu ei lange kokku sellega, mis naised tegelikult kogevad, mõtlevad ja tunnevad. Oma suhtlusruumi, s.o internetifoorumit võidakse tajuda privaatsena, sest on olemas teatud vaikiv eeldus, et selle leiavad internetiavarustest üles ja sealseid tekste loevad vaid need, kel on endal sarnane eluperiood ja kel on isiklikest kogemusest tulenev vajadus konkreetses internetirühmas osaleda. Niisamuti võib olla põhjuseks, miks jagavad naised enda isiklikke kehalisi kogemusi ning meditsiiniprotseduure vahendavaid tekste lihtsalt ligipääsetavas foorumis, et pole leitud (või ka soovitud leida) alternatiivi - kuigi naiste lapseootusega seotud teemadele keskenduvaid nii lihtsamini kui ka raskemini ligipääsetavaid vestlusringe on eestikeelse interneti virtuaalmaastikul mitmeid, on Perekool omataoliste seas siiski vanimaid, tuntumaid, ning suurima kasutajaskonnaga.

Ajaviidet kui foorumisse kirjutatud kogemuslugude funktsiooni võib kõige enam täheldada sünnituslugude puhul, s.o $95 \%$ analüüsitud lugudest. Teiste siserühmade puhul tuli ajaviide kogemuslugude funktsioonina esile, $11 \%$ triibupüüdjate lugudest, 3\% kõhukasvatajate lugudest ja 3\% ivf-kate lugudest. Sünnituslugude ajaviitelisus seisneb selles, et neid kirjutatakse teistega kogemuste võrdlemiseks, vastusena rühma ootusele jagada oma lugu, tagantjärgi reageeringuna teiste lugudele, kuid ka selles, et heidetakse nalja oma koge- 
muse üle ja pakutakse nii rühmakaaslastele meelelahutust. Triibupüüdjate, kõhukasvatajate ja ivf-kate lugude puhul saab ajaviitest rääkida peamiselt seoses kogemuste võrdlemisega ning loo kirjapanekuga enda teekonna lõpus. Erinevalt sünnituslugudest ei ole viimati mainitud kogemuslugudes üldjuhul kohta oma kogemuse üle nalja heitmisel. Niisamuti jagatakse oma lugusid harvem aja möödudes - põhjusena võib tuua, et soovitakse probleemne eluperiood unustada ning eluga edasi minna (foorumisuhtluse kontekstis võib see tähendada, et naine loobub konkreetses siserühmas aktiivsest osalemisest ning "kolib" edasi mõnda teise, uue eluperioodiga sobivamasse gruppi - näiteks võib Perekooli foorumeis olla selleks Beebi või Mitmikute alafoorum.

\section{Kokkuvõte}

Käesoleva uurimuse sihiks oli vaadelda Perekooli Rasestumise, Lapse ootuse ja Sünnituse alafoorumite siserühmade (rasestuda soovijad e triibupüüdjad, kehavälise viljastamise kogemusega naised e ivf-kad, lapseootajad e kõhukasvatajad ja sünnitanud naised) suhtluses eristuvate kogemuslugude funktsioone, et saada selgust, millist eesmärki või rolli täidavad need internetirühma toimimise seisukohast, ning millised on laiemad tähendused ja ajendid, miks jagavad naised isiklikke ja delikaatse sisuga tekste kergesti ligipääsetavas internetifoorumis. Kogemuslugude ja nendega seotud foorumikommentaaride analüüsist tulid esile järgmised funktsioonide kategooriad: lohutus ja abi, infovahetus ja nõuanded, hoiatus, eneseesitlus ning ajaviide.

Ilmnes, et kogemuslugude jagamine foorumis võib pakkuda lohutust ja abi nii lugude kirjutajaile kui ka lugejaile. Rasestuda sooviv, kehavälise viljastamise protseduuri läbiv ning last ootav naine võib tunda end oma seisundiga seoses üksikuna või isoleerituna, kui lähikonnas ei ole inimesi, kes jagavad temaga sarnaseid kogemusi ja arusaamu. Mõnikord võib naine otsustada teadlikult oma kogemustest, mõtetest ja tunnetest vaikida, kartes ümbritsevate inimeste vääritimõistmist või hukkamõistu. Näiteks naiste pikaaegsed probleemid rasestumisel ning kehaväline viljastamine näivad olevat teemad, millest laiem avalikkus väga vähe teab, ning seetõttu otsivad naised foorumist abi ja lohutust just neilt, kellel on sarnane kogemus. Nii kogemuslugude kirjutamisest kui ka lugemisest internetirühmas loodetakse rühmakaaslaste psühholoogilist tuge, ajendatuna arusaamast, et tõeliselt mõista ja aidata saab rasestumise, lapse ootuse või sünnitusega seotud probleemidega naist vaid see, kes on ise midagi sarnast kogenud. Seejuures mängivad vastastikuses abistamises olulist rolli nn edulood. Naine võib jagada oma lugu eesmärgiga saada vastutasuks teiste naiste õnneliku lõpuga lugusid, et ammutada neist jõudu toimetulemiseks ja 
eluga edasi minemiseks. Teisalt võib naine oma eduloo kirja panna selleks, et sisendada lootust ja pakkuda tuge teistele.

Rasestumise, lapseootuse, kehavälise viljastamise ja sünnituskogemustega naiste lood internetifoorumis toimivad infovahetusena selles mõttes, et need on oluliseks alternatiivseks või lisa infoallikaks sellele, mis saadakse lähikondlastelt ning arstidelt ja ämmaemandatelt. Samuti võib naine eelistada info hankimist teiste poolt foorumisse kirjutatud kogemuslugudest, sest tunneb, et ei leia meditsiinipersonaliga ühist keelt. Ühtlasi täidavad kogemuslood omamoodi mitteametliku nõustamise funktsiooni, sest need võimaldavad ligipääsu kogeja vaatepunktile. Need aitavad naistel paremini mõista oma seisundit ja saada teadlikumaks oma probleemi võimalikest erinevatest lahendustest. Nõnda võib nii oma kogemusloo jagamine kui ka teiste lugude lugemine aidata vähendada hirme ning olla abiks otsuste tegemisel. Kogemusloo kirjutajale võib sel olla arutelu algatav otstarve. Seejuures väärib internetirühma toimimise seisukohast esiletõstmist asjaolu, et kogemuslugude muust infovoost eristuv pikem narratiivne vorm (kogemuse, sellega seotud sündmuste ja emotsioonide detailne kirjeldamine) võimaldab saada rühmakaaslastelt spetsiifilisemat tagasisidet ja nõu otsuste tegemisel, kui seda annab üksnes fakti nentimine ning küsimuse esitamine.

Kogemuslugu võib toimida ka kui hoiatus, milles suunatakse naisi suhtluses meditsiinipersonaliga enda eest seisma ning vältima mõtteid ja tegevusi, mida hiljem kahetsetakse. Seejuures võib füüsilises ruumis toimuvate tegevuste kõrval olla kogemusloo kirjapanemise sihiks ka hoiatada internetikasutusega seotud ohtude eest.

Kogemuslood toimivad internetifoorumis eneseesitlusena selles mõttes, et need näitavad, kuidas naine oma kogemusega toime tuleb. Niisamuti võimaldavad kogemuslood naistel näidata ja tunda, et nad on osa sarnaste huvide, rõõmude ja muredega inimeste grupist. Rühmasisesel eneseesitlemisel toimivad kogemuslood kui visiitkaardid, mille abil on võimalik ennast teistele tutvustada, või mille põhjal teised konkreetse isiku rühmasuhtluses ära tunnevad. Samas ei ole need lood ligipääsetavusele vaatamata mõeldud auditooriumile väljaspool konkreetset internetirühma, vaid üksnes kaasteelistele, s.t sarnaste kogemustega rasestuda soovijatele lapse ootajaile ning sünnitajatele. Teisisõnu tajutakse kergesti ligipääsetavat (avalikku) internetikeskkonda konkreetsele huvigrupile kuuluvana.

Kogemuslugu võib pakkuda ajaviidet nii selle kirjapanijale kui ka loo lugejaile. Ajaviitelisus tuli kogemuslugude funktsioonina esile seoses kogemuste võrdlemisega ning "koos ootamisega”, kuid ka seoses tõsiasjaga, et kogemuslugude jagamisest triibupüüdmise, kehavälise viljastamise või lapseootuse teekonna lõpus on rühma argisuhtluses kujunenud omamoodi tava - naine, 
kes on leidnud ajaviidet ja meelelahutust teiste lugude lugemisest, pakub seda vastutasuks ka teistele. Niisamuti võib ajaviidet näha selles, et oma lugu jagatakse foorumis aja möödudes ka siis, kui konkreetne teema ja kogemus ei ole naise jaoks enam aktuaalne.

Mil määral ning mis kujul üks või teine kogemuslugude funktsioon esile tuleb, oleneb sellest, millised on kesksed kogemused, huvid, probleemid ja vajadused, mille ümber konkreetse siserühma suhtlus keskendub.

Lõpetuseks võib öelda, et internetifoorumisse kirjutatud kogemuslugude funktsioonide analüüs näitab ühelt poolt, kuidas toimivad internetirühmad ning milline otstarve on neis kogemuslugude vahetamisel. Teisalt võimaldab kogemuslugude funktsioonide vaatlus jõuda laiemate sotsiaalkultuuriliste tähendusteni, mis peegeldavad asjaolusid ja ajendeid, miks naised internetifoorumeisse oma lugusid jagama suunduvad ning miks on sedalaadi suhtlus neile vajalik. Positiivsete aspektide kõrval (üksteise toetamine ja abistamine) avanevad murekohad, probleemid ja puudujäägid, millega naistel tuleb silmitsi seista - seda nii meditsiinipersonaliga suheldes kui ka ühiskonnas valitsevate rasestamist, lapseootust ja sünnitust puudutavate arusaamade tõttu.

\section{Kommentaar}

1 Artikli valmimist on toetanud Haridus- ja Teadusministeeriumi institutsionaalne uurimisprojekt 2-43.

\section{Kirjandus}

Asplund Ingemark, Camilla 2013. Key Themes in Study of the Therapeutic Uses of Storytelling. Asplund Ingemark, Camilla (toim). Therapeutic Uses of Storytelling. An Interdisciplinary Approach to Narration as Therapy. Chapter 1. Lund: Nordic Academic Press, lk 7-20.

Boer, Marjolein \& Slatman, Jenny 2014. Blogging and Breast Cancer: Narrating One's Life, Body and Self on the Internet. Women's Studies International Forum 44, lk 17-25 (doi: 10.1016/j.wsif.2014.02.014).

Cohen, Jodi H. \& Raymond, Jennifer M. 2011. How the Internet is Giving Birth (to) a New Social order. Information, communication \& Society 14 (6), lk 937-957 (doi: 10.1080/1369118X.2011.582132).

Dégh, Linda 1985. Isikukogemuse narratiivide teooria. Vesik, Sander (tlk). Artikkel VTK raamatust. [The Theory of Personal Experience Narrative. Papers III. The 8th Congress for the International Society for Folk Narrative Research. Bergen, June 12th-17th 1984, edited by Reimund Kvideland \& Torunn Selberg. Bergen 1985, lk 233-242] (http://www. folklore.ee/seminar - 10. oktoober 2018). 
Glazer, Mark 1997. Functionalism. Green, Thomas A. (toim). Folklore. An Encyclopedia of beliefs, customs, tales, music, and art. 1: A-H. Santa Barbara, California: ABC-CLIO, lk 386-389 (http://www.rhymesworld.com/sitebuildercontent/sitebuilderfiles/2285284. pdf - 10. oktoober 2018).

Honko, Lauri 1984. Tühjad tekstid, täis tähendused. Müürsepp, Maris (tlk). Artikkel VTK raamatust. [On transformal meaning in folklore. ARV Scandinavian Yearbook of Folklore, edited by B. R. Jonsson, Uppsala, lk 95-125.] (http://www.folklore.ee/seminar 10. oktoober 2018).

Kaliarnta, Sofia \& Nihlén-Fahlquist, Jessica \& Roeser, Sabine 2011. Emotions and Ethical Considerations of Women Undergoing IVF-Treatments. HEC Forum 23 (4), lk 281-293. (doi: 10.1007/s10730-011-9159-4).

Kamppinen, Matti 2014. The Role of Theory in Folkloristics and Comparative Religion. Approaching Religion 4 (1), lk 3-12 (doi: 10.30664/ar.67531).

Kõiva, Mare 2009. Online Medicine. Communication and Narratives. Mare Kõiva (toim). Media \& Folklore. Contemporary Folklore IV. Tartu: ELM Scholarly Press, lk 162-183. (http://www.folklore.ee/rl/pubte/ee/cf/cf4/CF4_Koiva.pdf - 8. märts 2017).

Kõiva, Mare 2010. Patsiendinarratiivid internetis. Paal, Piret (toim). Inimene, tervis ja haigused. Terviseteemaline artiklikogumik "Medica”. Tänapäeva folkloorist 9. Tartu: EKM Teaduskirjastus, lk 217-250.

Laherand, Meri-Liis 2008. Kvalitatiivne uurimisviis. Tallinn: Sulesepp.

Lundby, Geir 2013. From Single to Double Stories of Identity. Asplund Ingemark, Camilla (toim). Therapeutic Uses of Storytelling. An Interdisciplinary Approach to Narration as Therapy. Chapter 3. Lund: Nordic Academic Press, lk 43-62.

Malik, Sumaira H. \& Coulson, Neil S. 2008. Computer-mediated infertility support groups: An explorary study of online experiences. Patient Education and Counseling 73, lk 105-113 (doi: 10.1016/j.pec.2008.05.024).

Marander-Eklund, Lena 2000. Variation in Repeated Interviews: Stories of Childbirth. Honko, Lauri (toim). Thick Corpus, Organic Variation and Textuality in Oral Tradition. Studia Fennica Folkloristika 7. Helsinki: Finnish Literature Society, lk 417-434.

Marander-Eklund, Lena 2001. Fieldwork among Birth-Givers: repeated Interviews as a Method of Collection. Wolf-Knuts, Ulrika \& Kaivola-Bregenhöj, Annikki (toim). Pathways: approaches to the study and teaching of Folklore. Turku/Abo: NNF Publications, lk 177-188.

Marander-Eklund, Lena 2002. Narrative Style. How to Dramatize a Story. Wolf-Knuts, Ulrika (toim). ARV. Nordic Yearbook of Folklore 58. Uppsala: The Royal Gustavus Adolphus Academy, lk 113-123.

Orgad, Shani 2005. Storytelling online. Talking Breast Cancer on the Internet. Digital formations 29. New York, Washington: Peter Lang.

Pilt, Maili 2013a. Kohtumispaik internetifoorum. Sissevaateid virtuaalrühma kollektiivsusesse. Kõiva, Mare (koost). Maailm ja multitasking. Tänapäeva folkloorist 10. Tartu: EKM Teaduskirjastus, lk 23-50 (doi: 10.7592/TF10.foorum). 
Pilt, Maili 2013b. Uurijahuvi - konflikt ja dialoog. "Teistmoodi laste" vanemate lood internetifoorumis. Kulasalu, Kaisa \& Päll, Lona \& Rumm, Kaija (koost). Kogemus, taju, keha: uurimusi noorteadlastelt. VanaVaraVedaja 8. Tartu: Tartu NEFA Rühm, lk 160-183.

Pilt, Maili 2017. Välitööd Internetis. Metsvahi, Merili (koost). Folkloristlikud välitööd. Kõrgkooliõpik. Tartu: Tartu Ülikooli Kirjastus, lk 104-119.

Phoenix, Ann 2013. Analysing narrative contexts. Andrews, Molly \& Squire, Corinne \& Tamboukou, Maria (toim). Doing Narrative Research. Second edition. Los Angeles, London, New Delhi, Singapore, Washington DC: Sage, lk 72-87 (doi: 10.4135/9781526402271.n4).

Polkinghorne, Donald E. 2013. Narrative Identity and Psychotherapy. Asplund Ingemark, Camilla (toim). Therapeutic Uses of Storytelling. An Interdisciplinary Approach to Narration as Therapy. Chapter 2. Lund: Nordic Academic Press, lk 21-42.

Reinaus, Reeli 2007. Enesepresentatsioon virtuaalses kogukonnas sünnituslugude ja perekooli foorumi kommentaaride näitel. Magistritöö. Tartu Ülikool, filosoofiateaduskond, kultuuriteaduste ja kunstide instituut (http://dspace.ut.ee/handle/10062/2926 - 10. oktoober 2018).

Reinaus, Reeli 2008. Pärimusliku ainese teke ja areng Perekoolis ning selle avaldumisvormid. Mäetagused 38, lk 33-54 (doi: 10.7592\&MT2008.38.reinaus).

Salmi-Niklander, Kristi 2009. Sündmus, kogemus ja jutustamine. Mäetagused 43, lk 19-39 (doi:10.7592/MT2009.43.salmi-niklander).

Sharf, Barbara F. 1997. Communicating Breast Cancer On-Line: Support and Empowerment on the Internet. Women \& Health 26 (1), lk 65-84 (doi: 10.1300/J013v26n01_05).

Squire, Corinne 2013. From Experience-Centered to Socioculturally-Oriented Approaches to Narrative. Andrews, Molly \& Squire, Corinne \& Tamboukou, Maria (toim). Doing Narrative research. Second edition. Los Angeles, London, New Delhi, Singapore, Washington DC: Sage, lk 47-71 (doi: 10.4135/9781526402271.n3).

Squire, Corinne \& Andrews, Molly \& Tamboukou, Maria 2013. Introduction. What is Narrative Research? Andrews, Molly \& Squire, Corinne \& Tamboukou, Maria (toim). Doing Narrative Research. Second edition. Los Angeles, London, New Delhi, Singapore, Washington DC: Sage, lk 1-26 (doi: 10.4135/9780857024992.d2).

Stahl, Sandra K. D. 1986. Personal Experience Stories. Dorson, Richard M. (toim). Handbook of American Folklore. Bloomington: Indiana University Press, lk 268-276.

Terp Høybye, Mette \& Johansen, Christoffer \& Tjørhøj-Thomsen, Tine 2005. Online interaction. Effects of storytelling in an internet breast cancer support group. Psychooncology 14, lk 211-220 (doi: 10.1002/pon.837).

Toscano, Sharyl, Eve \& Montgomery, Rebecca M. 2009. The Lived Experience of Women Pregnant (Including Preconception) Post In Vitro Fertilization Through the Lens of Virtual Communities. Health Care for Women International 30 (11), lk 1014-1036 (doi: 10.1080/07399330903159700). 
Wright, Kevin B. \& Bell, Sally B. 2003. Health-related Support Groups on the Internet: Linking Empirical Findings to Social Support and Computer-mediated Communication Theory. Journal of Health Psychology 8 (1). Sage Publications. London, New Delhi: Thousand Oaks, lk 39-54 (doi: 10.1177/1359105303008001429).

\title{
Summary
}

\section{Functions of personal experience stories related to conception, pregnancy, and childbirth on the Estonian internet family discussion forum www.perekool.ee.}

\section{Folkloristic theme analysis}

\author{
Maili Pilt \\ Doctoral student in folkloristics, University of Tartu \\ maili.pilt@ut.ee
}

Keywords: childbirth, conception, internet, in vitro fertilization, personal experience stories, pregnancy

The focus of the study was to take a look at the functions of telling personal experience stories on the Estonian internet family discussion forum Perekool (Family School) subforums dedicated to conception, pregnancy, and childbirth. The analysis was based on four groups of stories and their comments: "strip catchers" stories (stories of women who want to get pregnant), IVF (in vitro fertilization) stories, "belly growers" stories (stories of pregnant women), and childbirth stories. The aim was to find out which role these stories play from the point of view of the functioning of the internet group, and which are these broader socio-cultural meanings and motives why women share their personal stories with delicate content on the easily accessible internet forum. The following categories of functions of personal experience stories emerged from the research: support and help, information exchange and advice, warning, self-presentation, and entertainment.

Sharing personal experience stories on an internet forum can provide support and help for both their writers and readers. The woman who wants to get pregnant, is undergoing in vitro fertilization procedure or is expecting a baby can feel lonely or isolated if she has no close people with similar experiences and understandings of her condition (what is 'right' or 'wrong', 'normal' or 'abnormal'). Sometimes a woman prefers to conceal her experiences, thoughts, and feelings, because she is afraid of being misunderstood. For example, women's long-term problems related to getting pregnant and in vitro fertilization seem to be topics that the wider public knows very little about, and that is why women prefer to share their stories and get support and help on the internet forum from those who have similar experiences and thus may understand them better. Both writing and reading the personal experience stories provide psychological support to group members, driven by understanding that only the women who have experienced the same can truly help. The so-called 'success stories' play an important 
role in mutual assistance. A woman can share her success story with the aim of getting in return other women's stories with a happy ending or the aim may be to offer hope and support to others.

Personal experience stories function as information exchange in the sense that they are an important alternative or additional source of information that women get from their relatives, doctors, and midwives. Women may prefer to get information from others' experiences and stories posted on the internet forum because they have not found a common language with medical staff. For example, women with endometriosis write in their stories that the diagnosis was a shock for them because they did not know anything about it and the doctor gave them very little hope (or not at all) to become a mother. On the other hand, women have found advice and information suggesting they might still get pregnant from other women's stories. The stories have a kind of informal advisory function because they allow access to the experiencer's point of view. Both configuring your own experience into a story and reading about others' experiences help women better understand their condition and become aware of potential different solutions of their problems. The aim of the story writer may also be to initiate a discussion on her own experiences. In this respect, the study revealed that the longer narrative form (a detailed description of the experience, related events and emotions) can provide more specific feedback and advice from group members than a mere question-answer style conversation.

A personal experience story can also function as a warning that leads women to stand up for themselves in communication with medical staff and to avoid their own thoughts and activities that they might regret later. In addition to the activities in the physical space, the purpose of writing a story can be to warn against the risks associated with the use of the internet.

Personal experience stories work as self-presentation on the internet forum in the sense that they show how women manage their experience. The stories also enable women to show that they belong to a particular group of people with similar interests and experiences. So, there is only one meaningful 'my story' per person within the Family School subforums titled Conception, Pregnancy, and Childbirth. The personal experience stories on these forums function as business cards, which allow women to introduce themselves when they join the group and by which other group members identify them later in the discussions even if women participate anonymously (for that purpose anyone can use the pseudonym Cuckoo). However, in spite of accessibility of the discussion forum (the postings are easy to find by a search engine and can be read by all internet users), the women do not write their stories to present themselves and their stories to the general public, but only to peers, i.e., other women with similar experiences. The easily accessible (public) internet forum is perceived as private communication space of a particular interest group because there is an implicit assumption that the forum is used and the conversations there are read only by those who go through a similar life period and who need, based on personal experiences, to participate in the group.

A personal experience story can be entertaining for both the writer and the reader. Entertainment as the function of women's stories emerges in relation to comparing experiences and 'expecting together', but also in connection with the fact that sharing the story at the end of the journey of strip catching, in vitro fertilization or pregnancy has become an unwritten rule of the internet group - the woman who has spent time 
reading other's stories is expected to share her own story as well. Also, entertainment as a function emerges if, in the passage of time, women share their stories on the forum in response to other ones, when the concrete topic and experience are no longer relevant to them.

To what extent and in what form one or another of the functions of the experience stories emerges, depends on the core experiences, interests, problems, and needs of the concrete subgroup. 